\title{
GMR
}

\section{Performance of grain sorghum hybrids under drought stress using GGE biplot analyses}

\author{
P.S.C. Batista ${ }^{1}$, C.B. Menezes ${ }^{2}$, A.J. Carvalho ${ }^{1}$, A.F. Portugal ${ }^{2}$, E.A. Bastos ${ }^{3}$, \\ M.J. Cardoso ${ }^{3}$, C.V. Santos ${ }^{4}$ and M.P.M. Julio ${ }^{4}$ \\ ${ }^{1}$ Centro de Ciências Exatas e Tecnológicas, \\ Universidade Estadual de Montes Claros, Campus Janaúba, Janaúba, MG, Brasil \\ ${ }^{2}$ Núcleo de Desenvolvimento e Recursos Genéticos, Embrapa Milho e Sorgo, \\ Sete Lagoas, MG, Brasil \\ ${ }^{3}$ Setor de Produção Vegetal, Grupo de Pesquisa e Desenvolvimento, \\ Embrapa Meio-Norte, Teresina, PI, Brasil \\ ${ }^{4}$ Departamento de Ciências Agrárias, Universidade Federal de São João del-Rei, \\ Campus Sete Lagoas, Sete Lagoas, MG, Brasil \\ Corresponding author: C.B. Menezes \\ E-mail: cicero.menezes@embrapa.br
}

Genet. Mol. Res. 16 (3): gmr16039761

Received June 26, 2017

Accepted August 22, 2017

Published September 21, 2017

DOI http://dx.doi.org/10.4238/gmr16039761

Copyright (C) 2017 The Authors. This is an open-access article distributed under the terms of the Creative Commons Attribution ShareAlike (CC BY-SA) 4.0 License.

\begin{abstract}
The objective of this study was to estimate the adaptability and stability of grain sorghum hybrids grown under postflowering water stress and non-stress conditions. The trials were carried out in Nova Porteirinha-MG during the season of 2014 and 2015, and in Teresina-PI in the 2014 season. Twenty-nine-grain sorghum hybrids were evaluated, in a randomized complete block design, with three replications. Plots consisted of four lines with $3 \mathrm{~m}$ long. The grain yield data were submitted to the individual variance analysis, having considered the effects of the hybrids as fixed and the other effects as random. The joint analysis was carried out, and when the interaction genotypes $\mathrm{x}$ environments was significant, the grain yield data were submitted to the adaptability and stability analysis by the GGE biplot
\end{abstract}

Genetics and Molecular Research 16 (3): gmr16039761 
method. A substantial reduction in the grain yield in environments with water stress was found. The highest yielding hybrids under water stress conditions in Nova Porteirinha-MG were 50A50, AG1080, AG1090, DKB550, DKB590, Jade, and BM737, and the highest yielding hybrids under the water stress in Teresina-PI were 1G282, 1G244, and A9721R. Considering all environments, the highest yielding hybrids were $1 \mathrm{G} 282$, DKB540, A9721R, 1G100, and AG1090.

Key words: Sorghum bicolor; Abiotic stress; Drought tolerance; Plant breeding; Grain yield; GGE biplot

\section{INTRODUCTION}

Abiotic stresses are among the main constraints to the development of agriculture in the world. Among the abiotic stresses, water deficiency is the most limiting crop performance (Araus et al., 2002), with a direct effect on yield reduction, causing damages in the physiological and metabolic processes in all phases of plant development (Taiz and Zeiger, 2009).

The use of tolerant crops such as sorghum [Sorghum bicolor (L.) Moench] consists in one of the main strategies that can reduce the yield losses caused by water stress. The good adaptation of sorghum in environments with low water availability is associated with the xerophytic features and to efficient drought tolerance mechanism that this crop owns (Landau and Sans, 2012). Sorghum stands out among other cereals of economic importance like corn by the possibility of cultivation in areas without irrigation, in seasons and locals with the occurrence of erratic rainfall distribution (Xin et al., 2009). In Brazil, sorghum has been grown as a succession crop, i.e., second season after soybean. The sowing occurs after February when rain season is diminishing, and post-flowering water stress is widespread.

Even being one of the most drought-tolerant crops, under marked water stress the sorghum plant can suffer damages in all the development phases, and the reproductive phase is the most affected by the stress, reducing weight and number of grains (Subudhi et al., 2000; Menezes et al., 2015). The impacts caused by water stress in sorghum can be mitigated by genetic improvement for drought tolerance, exploiting the genetic variability that this species presents (Rosenow and Dahlberg, 2000).

For an accurate selection of drought tolerance, it is essential the evaluation of the genotypes in different environments, allowing the precise identification of those most adapted and stable. Thus, according to Menezes et al. (2015), the interaction genotypes x environments (GxE) plays an important role in the phenotypic expression of the drought tolerance.

Several methods, based on different concepts, have been described for evaluation of the GxE interaction and the determination of the phenotypic adaptability and stability. The methods of Lin and Binns (1988), AMMI (Zobel et al., 1988), Annicchiarico (1992), and GGE biplot (Yan et al., 2000) are most frequently used. Among these methods, both AMMI and GGE biplot, which utilized multivariate techniques associated with descriptive analyses, in combination or substitution of the univariate analyses, make easier the observation of complex interactions (Ma et al., 2004).

The GGE biplot method takes into consideration the effect of the genotype and the GxE interaction. In this method, only the main effect of the genotype and the GxE interaction are important. Thus, both must be considered simultaneously. So, it is considered that the

Genetics and Molecular Research 16 (3): gmr16039761 
main effect of environment does not present relevance in the selection of genotypes. The GGE biplot model does not separate the genotype from the GxE interaction, maintaining them together in two multiplicative terms (Yan et al., 2000).

In this way, the objective of this study was to check the adaptability and stability through the GGE biplot analysis of grain sorghum hybrids in environments with and without water stress.

\section{MATERIAL AND METHODS}

Three trials were carried out to evaluate the performance of the hybrids. Two at the Experimental Station of Embrapa Maize and Sorghum, in Nova Porteirinha-MG, in the seasons of 2014 and 2015, and one at the Experimental Station of the Embrapa Mid-North, in Teresina-PI, in the season of 2014. Both sites have a very well-defined rain season, with no rain from May to October. In the case of sorghum drought selection, the main target has been to find stress tolerance during grain-filling period.

Nova Porteirinha is situated in the mesoregion of the North of Minas Gerais, considered as a semi-arid area. The geographical coordinates are $15^{\circ} 48^{\prime} \mathrm{S}$ latitude and $43^{\circ} 18^{\prime} \mathrm{W}$ longitude. The climate, according to Köppen, is of the type Aw (tropical with dry winter). The soil of the experimental area is characterized as medium-textured Red-Yellow Latosol.

Teresina presents the geographic coordinates of $05^{\circ} 05^{\prime} \mathrm{S}$ latitude and $42^{\circ} 48^{\prime} \mathrm{W}$ longitude. The climate, according to the classification of Thornthwaite and Mather, is $\mathrm{C}_{1} \mathrm{sA}^{\prime} \mathrm{a}^{\prime}$, characterized as dry sub-humid, mega-thermal, with moderate water surplus in the summer. Teresina is located in a semi-arid area. The soil of the experimental area is a sandy loamtextured Dystrophic Yellow Argisol.

The maximum and minimum temperatures and the rainfall during the grown of the trials are presented in Figures 1 and 2.

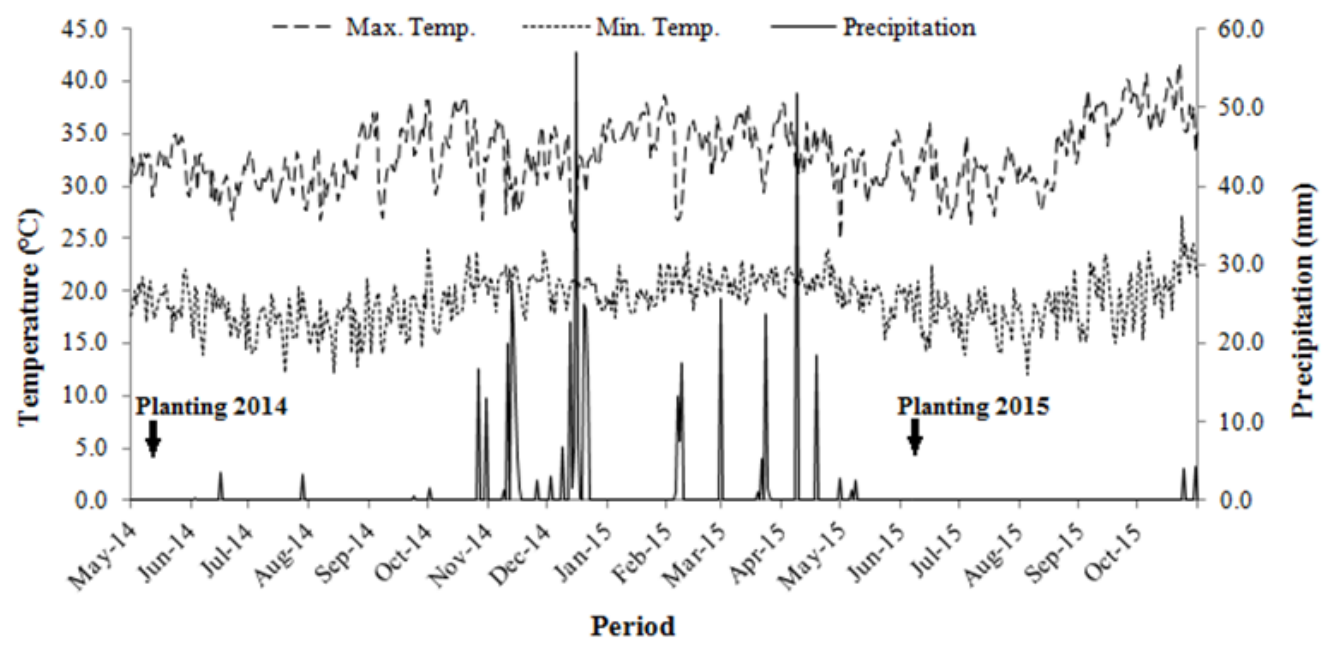

Figure 1. Rainfall $(\mathrm{mm})$, maximal and minimal temperature $\left({ }^{\circ} \mathrm{C}\right)$ during the trial period of 2014 and 2015 in Nova Porteirinha-MG (Source: INMET, 2015).

Genetics and Molecular Research 16 (3): gmr16039761 


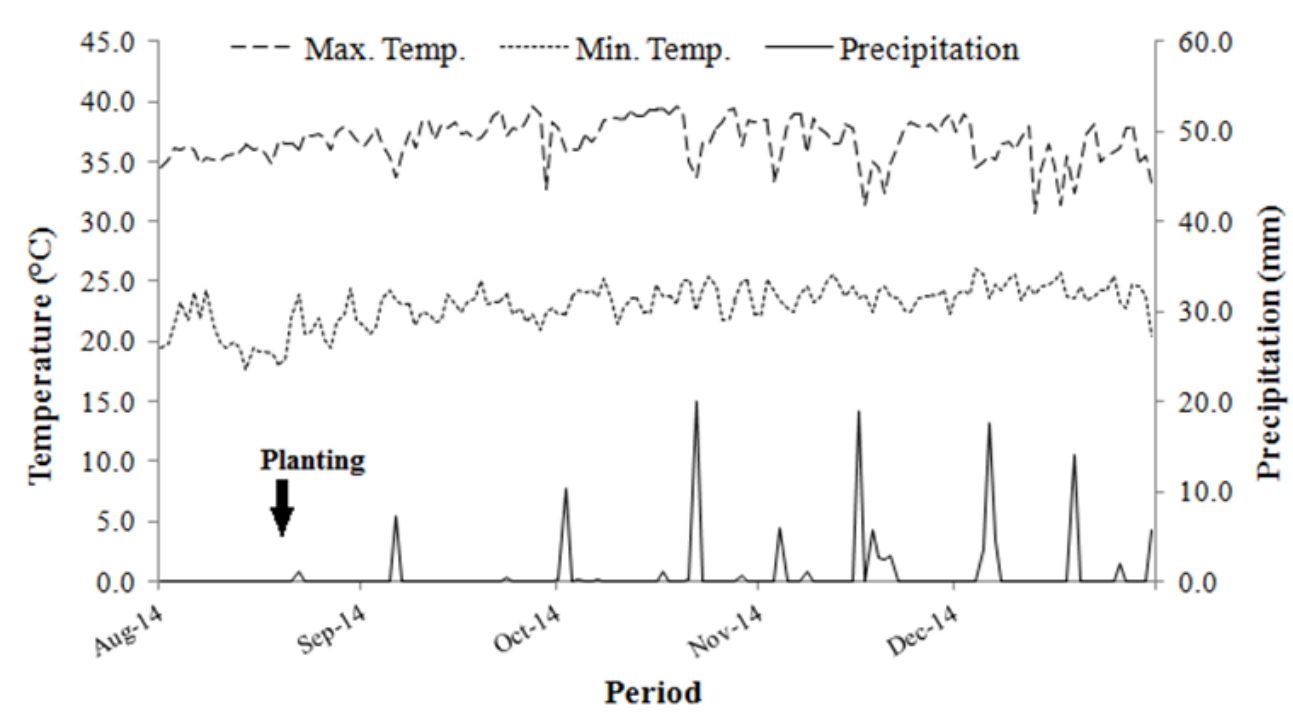

Figure 2. Rainfall $(\mathrm{mm})$, maximal and minimal temperature $\left({ }^{\circ} \mathrm{C}\right)$ during the trial period of 2014 in Teresina-PI (Source: INMET, 2015).

Twenty-nine commercial grain sorghum hybrids, belonging to the main seed companies of Brazil and among the most planted cultivars during the off-season in the Bioma Cerrado, were subjected to two moisture regimes. In treatment-1, the hybrids were wellwatered throughout the growing period to give full potential of the genotypes under nonstress conditions. In treatment-2, the cultivars received adequate watering from germination to boot stage (just before the flowering stage) after which no more watering was applied. This treatment simulated the post-flowering (terminal) moisture stress situation. Each combination of local and water regimes was considered one environment, totaling six environments.

Trials were irrigated using sprinklers spaced $12.0 \times 12.0 \mathrm{~m}$ apart, operating pressure of $250 \mathrm{kPa}$, nozzles of $4.0 \times 2.6 \mathrm{~mm}$ in diameter, and flow of $1.6 \mathrm{~m}^{3} / \mathrm{h}$. The irrigation management was performed based on the evapotranspiration of the crop and the irrigation summed to the rainfall in the trials with water stress ranged from 334.3 to $400.0 \mathrm{~mm}$ and in the trials without water stress ranged from 462.7 to $600.0 \mathrm{~mm}$.

An experimental design of randomized complete blocks was used, with three replications and plots of four rows of $3 \mathrm{~m}$ in length and $0.5 \mathrm{~m}$ between rows. The two central rows of each plot were harvested. Sowing was carried out with excess seeds and, after thinning at 30 days after sowing, the plant density was 180,000 plants/ha.

In Nova Porteirinha, starter fertilizers were applied using $250 \mathrm{~kg} / \mathrm{ha}$ 8-28-16 (NPK). Besides, $72 \mathrm{~kg} / \mathrm{ha} \mathrm{N}$ was side-dressed, using urea as a nitrogen source 30 days after planting. Sowing dates in Nova Porteirinha were May 9, 2014, and June 10, 2015. In Teresina, planting fertilization consisted of $80 \mathrm{~kg} / \mathrm{ha} \mathrm{P}_{2} \mathrm{O}_{5}, 75 \mathrm{~kg} / \mathrm{ha} \mathrm{N}, 35 \mathrm{~kg} / \mathrm{ha} \mathrm{K} \mathrm{K}_{2} \mathrm{O}$, and $3 \mathrm{~kg} / \mathrm{ha}$ zinc. Thirtytwo days after planting, side-dressing fertilization with $75 \mathrm{~kg} / \mathrm{ha} \mathrm{N}$ and $35 \mathrm{~kg} / \mathrm{ha} \mathrm{K}_{2} \mathrm{O}$ was carried out. Sowing date in Teresina-PI was August 22, 2014.

The crop management consisted of two hand hoeings and applications of insecticides for the control of armyworm. Soon after flowering, the panicles were covered with polyethylene bags to prevent birds damaging. 
Grain yield was evaluated by weighing the grain mass, corrected to $13 \%$ moisture, transforming the results to $\mathrm{kg} / \mathrm{ha}$.

Data were submitted to the individual variance analysis, considering the effect of the hybrids as fixed and the other effects as random. Since it was detected that the ratio between the greatest and the smallest mean square of the individual variance analysis did not exceed the 7:1 ratio, the joint analysis of the trials was performed (Banzatto and Kronka, 2006). After that, the data were submitted to the adaptability and stability analysis using the GGE biplot method (Yan et al., 2000).

The GGE Biplot model used was:

$$
Y_{i j}-\mu-\beta_{j}=y_{1} \varepsilon_{i 1} \rho_{j 1}+y_{2} \varepsilon_{i 2} \rho_{j 2}+\varepsilon_{i j} \quad \text { (Equation 1) }
$$

where $Y_{i j}$ is the grain yield average of genotype in environment $\mathrm{j} ; \mu$ is the general mean of the observations; $\beta_{j}$ is the principal effect of environment; $y_{1}$ and $y_{2}$ are the scores associated with the first (PC1) and second principal component (PC2), respectively; $\varepsilon_{1}$ and $\varepsilon_{2}$ are the values of PC1 and PC2 of the genotype $i$, respectively; $\rho_{j 1}$ and $\rho_{j 2}$ are the values of PC1 and PC2 for the environment $\mathrm{j}$, respectively; and $\varepsilon_{i j}$ is the error associated with the model of the $\mathrm{i}$-th genotype and j-th environment (Yan et al., 2000). The analysis was developed using the GGEGui package implemented in the R software (R Development Core Team, 2016).

\section{RESULTS AND DISCUSSION}

There were significant differences between the sources of hybrids $(\mathrm{G})$, environments (E) and interaction GxE (Table 1). The results showed that the hybrids performed differently under the two water regimes, and the significant interaction GxE made more difficult the selection of a hybrid that performed well in both conditions. The coefficient of variation was below 20\%, and it is considered satisfactory for field trials when yield is measured (PimentelGomes, 2009).

Table 1. Summary of the joint analysis of variance concerning grain yield of twenty-nine-grain sorghum hybrids grown under water stress and non-stress conditions in Nova Porteirinha-MG, in 2014 and 2015 seasons, and in Teresina-PI, in the 2014 season.

\begin{tabular}{l|c|c}
\hline Source of variation & d.f. & Mean squares \\
\hline Hybrids $(\mathrm{H})$ & 28 & $7084398.8^{* *}$ \\
\hline Environments (E) & 5 & $410545272.0^{* *}$ \\
\hline Block & 2 & $2187316.0^{*}$ \\
\hline HxE & 140 & $1881070.8^{* *}$ \\
\hline Error & 346 & 524955.9 \\
\hline CV $(\%)$ & & 16.76 \\
\hline
\end{tabular}

**Significant at $1 \%$ of probability. $*$ Significant at $5 \%$ of probability. ${ }^{\mathrm{n}}$ Nonsignificant by the $\mathrm{F}$-test. d.f. $=$ degrees of freedom, $\mathrm{CV}=$ coefficient of variation.

The general mean considering the six trials was $4323 \mathrm{~kg} / \mathrm{ha}$ (Table 2), superior to the national mean achieved in the 2014 season, which was $2587 \mathrm{~kg} / \mathrm{ha}$ (CONAB, 2015). The average grain yield of the hybrids was inferior to the national mean only in Nova PorteirinhaMG, in 2015, and in Teresina-PI, in the trials with water stress (Table 2).

Genetics and Molecular Research 16 (3): gmr16039761 
P.S.C. Batista et al.

Considering the means of the trials under stress and non-stress conditions in each season, there was a reduction of $35 \%$ in Nova Porteirinha-MG, in 2014, 65\% in 2015, and $50 \%$ in Teresina-PI (Table 2). These results showed that water stress intensities were different from a place to another, and in the same place but different years, proving the importance of other edaphoclimatic factors, linked to water stress, and of the experiment management in different years and locations. Grain yield reduction caused by water stress was also observed by Menezes et al. (2015), who found reductions of 39\% in grain sorghum lines, and by Tardin et al. (2013), who found reductions of 54\% in grain sorghum hybrids.

Table 2. Mean of grain yield $(\mathrm{kg} / \mathrm{ha})$ of twenty-nine-grain sorghum hybrids grown under water stress and nonstress conditions in Nova Porteirinha-MG, in 2014 and 2015 seasons, and in Teresina-PI, in the 2014 season.

\begin{tabular}{|c|c|c|c|c|c|c|c|c|}
\hline Number & Hybrid & NS14 & $\mathrm{NC14}$ & NS15 & $\mathrm{NC15}$ & TS14 & TC14 & Mean \\
\hline 1 & BRS 310 & 7905 & 4934 & 5632 & 2909 & 1900 & 1807 & 4181 \\
\hline 2 & BRS 330 & 7095 & 5069 & 5109 & 2232 & 2028 & 1828 & 3894 \\
\hline 3 & BRS 332 & 6672 & 2462 & 5137 & 638 & 2388 & 1279 & 3096 \\
\hline 4 & $1 \mathrm{G} 100$ & 9800 & 4247 & 6473 & 3383 & 4336 & 2918 & 5193 \\
\hline 5 & $1 \mathrm{G} 220$ & 5355 & 3031 & 5069 & 1590 & 3167 & 827 & 3173 \\
\hline 6 & $1 \mathrm{G} 244$ & 7741 & 5340 & 6874 & 2215 & 4013 & 1730 & 4652 \\
\hline 7 & $1 \mathrm{G} 282$ & 8597 & 6983 & 7400 & 2872 & 5306 & 3135 & 5716 \\
\hline 8 & $50 \mathrm{~A} 10$ & 7887 & 3737 & 7260 & 2446 & 4516 & 2164 & 4668 \\
\hline 9 & $50 \mathrm{~A} 50$ & 6752 & 6650 & 6250 & 1664 & 4086 & 1703 & 4517 \\
\hline 10 & $50 \mathrm{~A} 70$ & 7274 & 4499 & 6179 & 1320 & 3522 & 2591 & 4231 \\
\hline 11 & AG 1040 & 7879 & 4789 & 5511 & 1015 & 4113 & 2098 & 4234 \\
\hline 12 & AG 1060 & 6564 & 2599 & 5014 & 1072 & 3266 & 1505 & 3337 \\
\hline 13 & AG 1080 & 8392 & 5597 & 6552 & 2192 & 3003 & 1516 & 4542 \\
\hline 14 & AG 1090 & 8529 & 6694 & 6633 & 2705 & 4345 & 586 & 4916 \\
\hline 15 & AS 4615 & 7380 & 4742 & 6050 & 3144 & 3584 & 1332 & 4372 \\
\hline 16 & AS 4625 & 5494 & 4735 & 6604 & 2909 & 4099 & 2008 & 4308 \\
\hline 17 & AS 4639 & 6977 & 4367 & 7223 & 2179 & 3598 & 1202 & 4258 \\
\hline 18 & DKB 540 & 7275 & 7925 & 6374 & 2733 & 5754 & 3023 & 5514 \\
\hline 19 & DKB 550 & 7665 & 5774 & 5991 & 1836 & 3531 & 1862 & 4443 \\
\hline 20 & DKB 590 & 7232 & 5569 & 6067 & 1910 & 4203 & 1238 & 4370 \\
\hline 21 & Jade & 6570 & 6602 & 5450 & 2501 & 3392 & 1661 & 4363 \\
\hline 22 & A 6304 & 6744 & 3731 & 6134 & 1317 & 3008 & 1807 & 3790 \\
\hline 23 & BM 737 & 8080 & 5766 & 6184 & 3172 & 3700 & 1184 & 4681 \\
\hline 24 & Buster & 6809 & 3024 & 5989 & 2135 & 3162 & 2726 & 3974 \\
\hline 25 & Bravo & 6917 & 2913 & 6535 & 1488 & 4300 & 2836 & 4165 \\
\hline 26 & FOX & 5815 & 4454 & 5239 & 2484 & 2438 & 1963 & 3733 \\
\hline 27 & A 9721 R & 8569 & 5852 & 6178 & 2509 & 4950 & 3398 & 5243 \\
\hline 28 & A 9735 R & 7265 & 1729 & 6782 & 1371 & 4198 & 843 & 3698 \\
\hline 29 & 1167092 & 6558 & 4670 & 6379 & 2680 & 3348 & 945 & 4097 \\
\hline Mean & & 7303 & 4775 & 6147 & 2159 & 3698 & 1852 & 4323 \\
\hline
\end{tabular}

NS14: Nova Porteirinha under non-stress conditions in the 2014 season; NC14: Nova Porteirinha under water stress conditions in the 2014 season; NS15: Nova Porteirinha under non-stress conditions in the 2015 season; NC15: Nova Porteirinha under water stress conditions in the 2015 season; TS14: Teresina under non-stress conditions in the 2014 season; TC14: Teresina under water stress conditions in the 2014 season.

According to Menezes et al. (2015) in drought-tolerance works, it is recommended that water stress reduce yield above $30 \%$ to discriminate the tolerant genotypes from the susceptible ones. A reduction in grain yield under stress conditions was expected as stress reduces the translocation of photoassimilates to the grains, resulting in smaller and fewer grains.

In the GGE biplot method, $\mathrm{PC} 1$ and $\mathrm{PC} 2$ are derived from the decomposition of the singular values of the effects of the genotypes $(\mathrm{G})$ and the interaction GxE. PC1 indicates that the adaptability of the genotypes is highly correlated to yield, whereas PC2 indicates the phenotypic stability; then, the genotypes with PC2 closer to zero are more stable (Yan et al., 2000). In the present study, PC1 and PC2 accounted for 53.33 and $18.96 \%$ of the total variation of the data, respectively (Figure 3). These values give consistency to the explanation of the 
total variation of the yield performance of the hybrids, plus the interaction with environments $(\mathrm{G}+\mathrm{GxE})$.

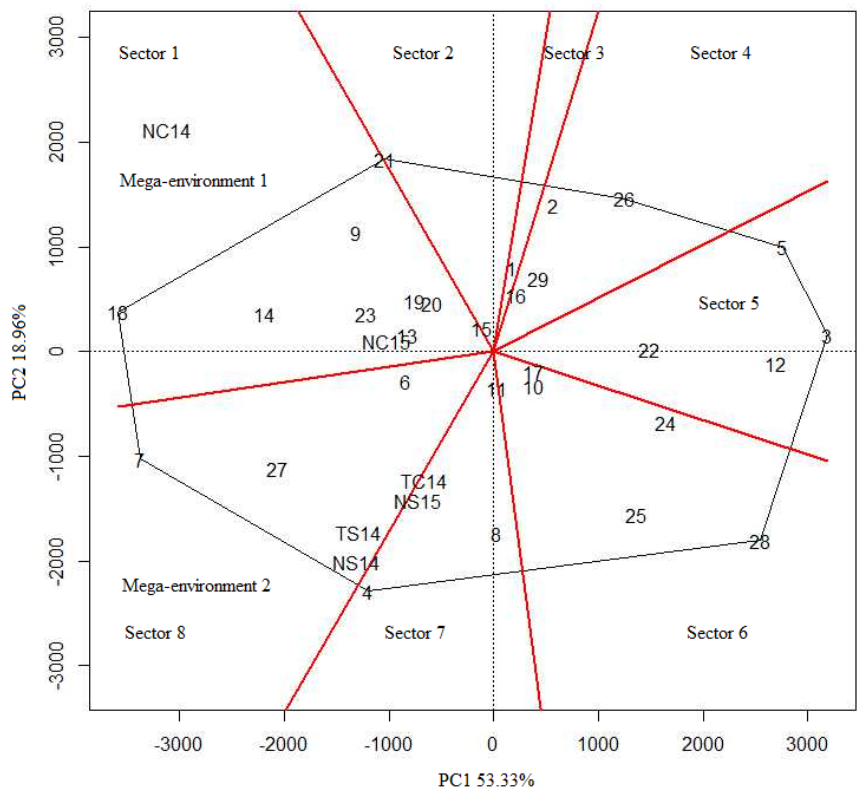

Figure 3. Sectors and mega-environments obtained by the GGE biplot model for grain yield of twenty-nine sorghum hybrids grown under water stress and non-stress conditions in Nova Porteirinha-MG, in 2014 and 2015 seasons, and in Teresina-PI, in the 2014 season. For abbreviations, see legend to Table 2.

In Figure 3, there is a formation of a polygon by the connection of the vertices farthest from the origin of the biplot, being formed by the hybrids DKB 540 (18), Jade (21), FOX (26), $1 \mathrm{G} 220$ (5), BRS 332 (3), A 9735 R (28), $1 \mathrm{G} 100$ (4), and 1G 282 (7). All the other hybrids are situated inside that polygon. The graphic was divided into eight sectors by the vectors coming from the biplot center $(0 ; 0)$, perpendicular to the polygon sides.

When different hybrids are adapted to groups of different environments, the variation between groups is greater than within the group, and there is the formation of a mega-environment (Yan and Kang, 2003). In biplot, the mega-environments are the sectors that contain one or more environments. Thus, in the present study, there was the formation of two mega-environments. In mega-environment 1 , the environments from Nova Porteirinha were grouped under water stress in 2014 and 2015 (NC14 and NC15). In mega-environment 2, the environments from TeresinaPI were grouped under water stress (TC14) and non-stress conditions (TS14), and from Nova Porteirinha under non-stress conditions in 2014 (NS14) and 2015 (NS15).

The hybrids situated on the vertices of each sector present the best or worst performance in that sector (Yan and Tinker, 2006). Hybrid DKB 540 (18) was the vertex of mega-environment 1 . Thus, it was the most adapted to the environments of Nova Porteirinha under water stress in 2014 and 2015, presenting greater yield in those environments. Hybrids 50A50 (9), AG 1080 (13), AG 1090 (14), DKB 550 (19), DKB 590 (20), Jade (21), and BM 737 (23) presented good adaptation to these environments. Thus, these are the hybrids that presented higher yields under water stress in Nova Porteirinha.

Genetics and Molecular Research 16 (3): gmr16039761 
For the other environments, hybrid $1 \mathrm{G} 282$ (7) was the most adapted because it was the vertex of mega-environment 2 and hybrids 1G 244 (6) and A 9721 R (27) also showed good adaptation to these environments. As the TC14 and NS15 environments were positioned on the division of sectors seven and eight, the hybrids belonging to the two sectors presented good adaptation to these environments (Figure 3). So, the hybrids with higher yields under water stress conditions in Nova Porteirinha were DKB 540, 50A50, AG 1080, AG 1090, DKB 550, DKB 590, Jade, and BM 737 and the hybrids with higher yields under stress conditions in Teresina-PI were $1 \mathrm{G} 282,1 \mathrm{G} 244$, and A $9721 \mathrm{R}$.

Even the highest yielding hybrids presented a reduction in grain yield when comparing trials under stress to those under non-stress trials. The reduction in grain yield in Nova Porteirinha in 2014 for hybrids 50A50, AG 1080, AG 1090, DKB 550, DKB 590, and BM 737 was of 73.4, 66.6, 59.2, 69.3, 68.5, and 48.7\%, respectively. In Nova Porteirinha, in the year of 2015, the reduction in grain yield for hybrids 50A50, AG 1080, AG 1090, DKB 550, DKB 590, and BM 737 was of 73.4, 66.6, 59.2, 69.3, 68.5, and 48.7\%, respectively. Hybrid Jade, in Nova Porteirinha, in the year of 2014, presented equivalent yield in the environments with and without water stress. However, in 2015, the reduction in the water stress was $54.1 \%$. For

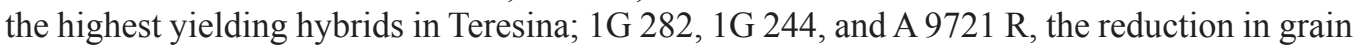
yield under the water stress condition was of $40.9,56.9$, and $31.4 \%$, respectively (Table 2 ).

The hybrids grouped in sectors that do not contain environments are not among the highest yielders in any of the environments, being considered unfavorable to the evaluated locals (Karimizadeh et al., 2013). The selection of the best hybrids, based on their performance, allows a safer recommendation to the farmer concerning planting seasons and locals where water stress can occur, like the off-season in Cerrado and the Northwestern of Brazil. Another advantage is the selection of the hybrids most responsive to a possible water increasing.

In the "mean vs stability" biplot (Figure 4), it is possible to obtain hybrids with high yield and high stability using a mega-environment, making it possible, in that way, to indicate the best hybrids for each particular environment (Yan et al., 2007).

In Figure 4, a straight line was drawn with an arrow passing through the origin of the biplot. The direction of the arrow shows the highest grain yield, with the sorghum hybrids being ranked along the line. The greater the projection distance of the hybrid regarding this straight line, the lower its stability is (Yan, 2011). Therefore, the highest yielding hybrids with mean above the general mean of all the environments were 1G 282 (7), DKB 540 (18), A 9721 R (27), $1 \mathrm{G} 100$ (4), and AG 1090 (14), presenting average yield in all environments of 5716, $5514,5243,5193$, and $4916 \mathrm{~kg} / \mathrm{ha}$, respectively (Table 2 ).

Among the highest yielding hybrids, $1 \mathrm{G} 282$ (7) and A $9721 \mathrm{R}(27)$ were the most stable, while hybrids DKB 540 (18), 1G 100 (4), and AG 1090 (14) were the most unstable. Besides, the lowest yielding hybrids were BRS 332 (3), 1G 220 (5), and AG 1060 (12) (Figure 4), with the average yield in all the environments of 3096, 3173, and $3337 \mathrm{~kg} / \mathrm{ha}$, respectively (Table 2).

The hybrids Jade (21), Bravo (25), and A $9735 \mathrm{R}$ (28) were the most unstable, and they contributed the most to the GxE interaction. The most stable hybrids were A9721 R (27), $1 \mathrm{G} 244$ (6), AS4515 (15), AG1040 (11), and AS4639 (17), being those that contributed least to the interaction.

In Figure 5, it is possible to observe the formation of concentric circles around the average grain yield, and the closer to the center of the concentric circles the more useful the hybrid is; what means that it presents the best average performance. When estimating the adaptability and stability, this is very important because it is not worth if a hybrid is stable but has a low yield (Yan, 2011). The most useful hybrid was 1G282 (7), followed by hybrids

Genetics and Molecular Research 16 (3): gmr16039761 
A9721R (27), 1G100 (4), and DKB540 (18). The high stability associated with a high yielding performance is essential for the recommendation of a hybrid, principally to environments or seasons with high rainfall instability, as in the off-season cultivation in Brazil.

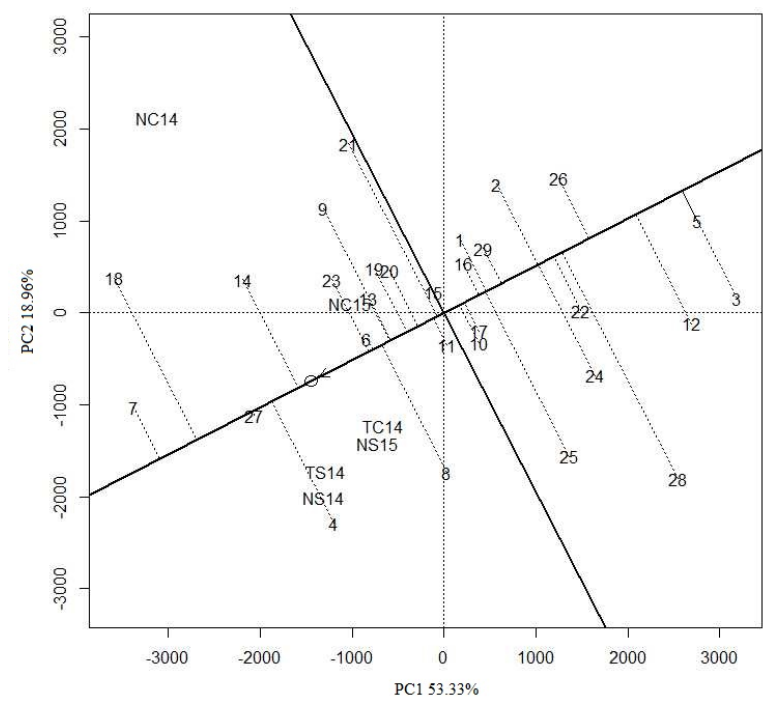

Figure 4. Mean versus stability according to the GGE biplot model for grain yield of twenty-nine sorghum hybrids grown under water stress and non-stress conditions in Nova Porteirinha-MG, in 2014 and 2015 seasons, and in Teresina-PI, in the 2014 season. For abbreviations, see legend to Table 2.

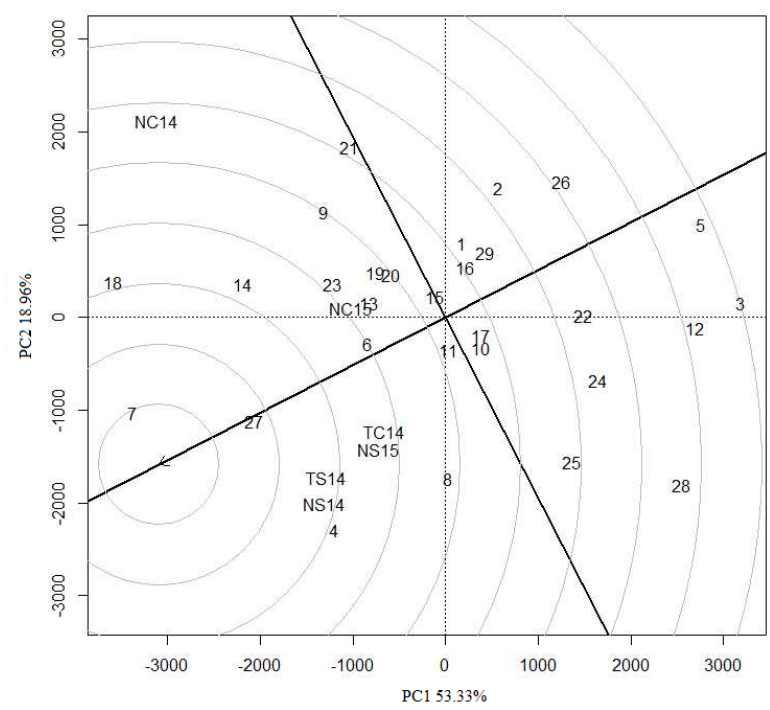

Figure 5. Classification of twenty-nine-grain sorghum genotypes according to the GGE biplot model for grain yield of 29 sorghum hybrids grown under water stress and non-stress conditions in Nova Porteirinha-MG, in 2014 and 2015 seasons, and in Teresina-PI, in the 2014 season. For abbreviations, see legend to Table 2.

Genetics and Molecular Research 16 (3): gmr16039761 
Figure 6 illustrates the relationship between grain yield and environmental stability. Vectors with origin on the center of biplot link the environments. According to Yang et al. (2009), the size of the vectors indicates the stability of the environments. So, environments with smaller vectors are more stable. Thus, $\mathrm{NC} 15$ was the environment that less contributed to the GxE interaction, presenting the smallest yield difference among the evaluated hybrids. Furthermore, $\mathrm{NC1} 4$ was the environment that presented the largest vector, thus, the environment that most contributed to the GxE interaction.

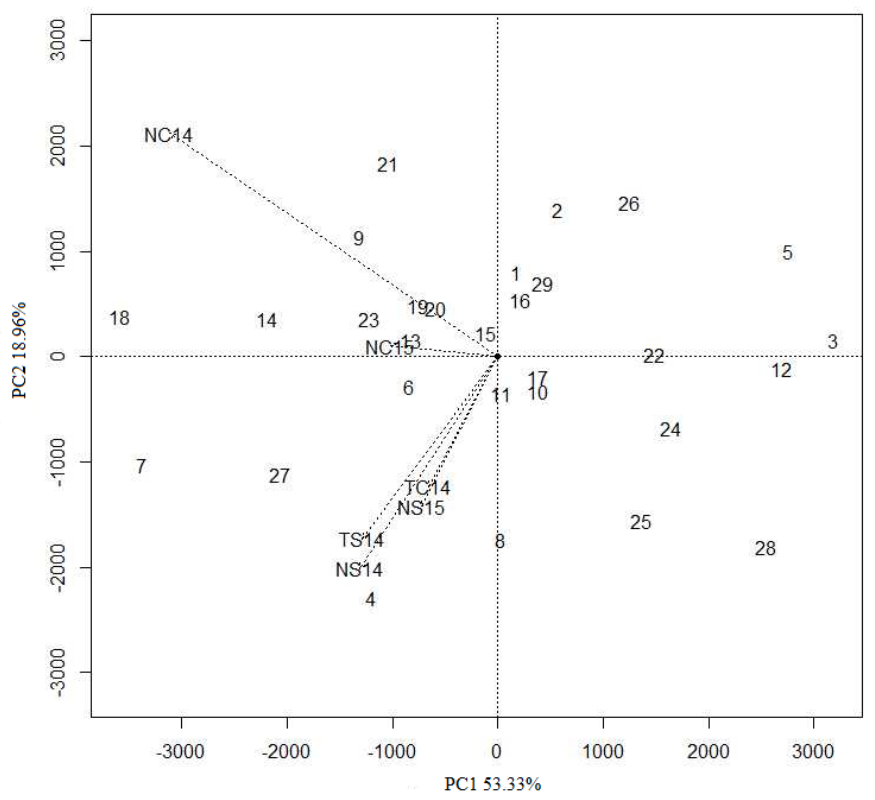

Figure 6. Relationship between the environments obtained by the GGE biplot model for grain yield of twenty-nine sorghum hybrids grown under water stress and non-stress conditions in Nova Porteirinha-MG, in 2014 and 2015 seasons, and in Teresina-PI, in the 2014 season. For abbreviations, see legend to Table 2.

The changes in grain yield stability in Nova Porteirinha in the environments under water stress in the seasons 2014 and 2015 can be explained by weather conditions, which varied from a year to another. In 2014, planting was carried out in May, with higher temperatures at the beginning of plant development, but at flowering time and grain filling, the temperatures were lower. In 2015, the planting was carried out in June, with milder temperatures during the initial development of the plants, but in the reproductive period of the plants, temperatures were highest, maximizing the effects of water stress on the plants (Figure 1). A different effect was observed in the same place in the non-stress environments, with smaller variation in the grain yield stability between the two periods. The normal water supplying minimized the effect of the high temperatures observed in 2015.

\section{CONCLUSIONS}

Water stress reduced grain yield in sorghum between 35\% (Nova Porteirinha-MG, 2014) and 65\% (Nova Porteirinha-MG, 2015). 
The highest yielding hybrids under the water stress conditions in Nova Porteirinha were 50A50, AG1080, AG1090, DKB550, DKB590, Jade, and BM737 and the highest yielding ones under the water stress conditions in Teresina were $1 \mathrm{G} 282,1 \mathrm{G} 244$, and A9721R

Considering all the six environments, the best hybrids were $1 \mathrm{G} 282$, DKB540, A9721R, 1G100, and AG1090.

\section{Conflicts of interest}

The authors declare no conflict of interest.

\section{ACKNOWLEDGMENTS}

Research supported by Embrapa Milho e Sorgo and Conselho Nacional de Desenvolvimento Científico e Tecnológico (CNPq).

\section{REFERENCES}

Annicchiarico P (1992). Cultivar adaptation and recommendation from alfalfa trials in Northern Italy. J. Genet. Breed. 46: 269-278.

Araus JL, Slafer GA, Reynolds MP and Royo C (2002). Plant breeding and drought in C3 cereals: what should we breed for? Ann. Bot. 89: 925-940. https://doi.org/10.1093/aob/mcf049

Banzatto DA and Kronka SN (2006). Experimentação agrícola. 4. ed. FUNEP, Jaboticabal.

CONAB (Companhia Nacional de Abastecimento) (2015). Acompanhamento da safra brasileira de grãos. Vol. 2, Safra 2014/15, No. 5. Quinto Levantamento, Brasília.

Karimizadeh R, Mohammadi M, Sabaghni N, Mahmoodi AA, et al. (2013). GGE biplot analysis of yield stability in multienvironment trials of lentil genotypes under rainfed condition. Not. Sci. Biol. 6: 256-262.

INMET (2015). Estações automáticas. Brasília, DF: Ministério da agricultura, pecuária e abastecimento. Available at [http://www.inmet.gov.br]. Accessed on November 10, 2015.

Landau EC and Sans LMA (2012). Clima. In: Cultivo do sorgo (Rodrigues JAS, ed.). 8a. ed. Embrapa Milho e Sorgo, Sete Lagoas (Sistema de Produção, 2).

Lin CS and Binns MR (1988). A superiority measure of cultivar performance for cultivar x location data. Can. J. P. Sci 68: 193-198. https://doi.org/10.4141/cjps88-018

Ma BL, Yan W, Dwyer LM, Fregeau-Reid J, et al. (2004). Graphic analysis of genotype, environment, nitrogen fertilizer, and their interactions on spring wheat yield. Agron. J. 96: 169-180.

Menezes CB, Ribeiro AS, Tardin FD, Carvalho AJ, et al. (2015). Adaptabilidade e estabilidade de linhagens de sorgo em ambientes com e sem restrição hídrica. Rev. Bras. Milho Sorgo 14: 101-115. https://doi.org/10.18512/1980-6477/ $\underline{\text { rbms.v14n1p101-115 }}$

Pimentel-Gomes F (2009). Curso de estatística experimental. 15. ed. FEALQ, Piracicaba, 451.

R Development Core Team (2016). R: a language and environment for statistical computing. Foundation for Statistical Computing, Vienna, Austria.

Rosenow DT and Dahlberg JA (2000). Collection, conversion and utilization of sorghum. In: Sorghum: Origin, History, Technology and Production (Smith CW and Frederiksen RA, eds.). New York, USA.

Subudhi PK, Rosenow DT and Nguyen HT (2000). Quantitative trait loci for the stay green trait in sorghum (Sorghum bicolor L. Moench): consistency across genetic backgrounds and environments. Theor. Appl. Genet. 101: 733-741. https://doi.org/10.1007/s001220051538

Taiz L and Zeiger E (2009). Fisiologia vegetal. 4.ed. Artmed, Porto Alegre.

Tardin FD, Almeida Filho JE, Oliveira CM, Leite CEP, et al. (2013). Avaliação agronômica de híbridos de sorgo granífero cultivados sob irrigação e estresse hídrico. Rev. Bras. Milho Sorgo 12: 102-117. https://doi.org/10.18512/1980-6477/rbms.v12n2p102-117

Xin Z, Aiken R and Burke J (2009). Genetic diversity of transpiration efficiency in sorghum. Field Crops Res. 111: 74-80. https://doi.org/10.1016/j.fcr.2008.10.010

Yan W (2011). GGE Biplot vs. AMMI Graphs for Genotype-by-Environment Data Analysis. J. Indian Soc. Agric. Stat. 65: 181-193.

Genetics and Molecular Research 16 (3): gmr16039761 
Yan W and Kang MS (2003). GGE biplot analysis: a graphical tool for breeders, geneticists, and agronomists. Boca Raton, Flórida.

Yan W and Tinker A (2006). Biplot analysis of multi environment trial data: principles and applications. Can. J. Plant Sci. 86: 623-645. https://doi.org/10.4141/P05-169

Yan W, Hunt LA, Sheng QL and Szlavnics Z (2000). Cultivar evaluation and mega-environment investigation based on the GGE Biplot. Crop Sci. 40: 597-605. https://doi.org/10.2135/cropsci2000.403597x

Yan W, Kang MS, Ma B, Woods S, et al. (2007). GGE biplot vs. AMMI analysis of genotype-by-environment data. Crop Sci. 47: 643-653. https://doi.org/10.2135/cropsci2006.06.0374

Yang RC, Crossa J, Cornelius PL and Burgueño J (2009). Biplot analysis of genotype x environment interaction: proceed with caution. Crop Sci. 49: 1564-1576. https://doi.org/10.2135/cropsci2008.11.0665

Zobel RW, Wright MJ and Gauch HG (1988). Statistical analysis of a yield trial. Agron. J. 80: 388-393. https://doi. org/10.2134/agronj1988.00021962008000030002x

Genetics and Molecular Research 16 (3): gmr16039761 